\title{
Den krænkede religion. Habermas, Honneth og profetens turban
}

\author{
Jonas Jakobsen
}

Jeg diskuterer i denne artikel en rekke principielle spørgsmål angående det der kaldes «religionens genkomst» i det moderne demokrati. Mit hovedeksempel er den såkaldte «Muhammed-krise» (efterfølgende kaldet «karikaturkrisen»), som stadigvaek debatteres med stor intensitet i nationale og internationale sammenhoenge. De tre hovedsporgsmål lyder: (1) Hvilken plads kan religiøse synspunkter og ytringer gøre krav på i den demokratiske offentlighed? (2) Kan vi indholdsmoessigt fastsoette grensen for religiøs blasfemi ved lov eller står den til løbende demokratisk debat? (3) I hvilken grad kan religiøse minoritetsgrupper kroeve anerkendelse fra - og beskyttelse mod - majoritetskulturen i moderne, liberale demokratier? Til det første spørgsmål svarer jeg med Jürgen Habermas at religiøse grupper bør forsøge at oversette deres holdninger til ikke-religiøse argumenter, samtidig med at denne oversoettelse afforskellige årsager ikke kan fremtvinges retsligt eller afkreves som betingelse for demokratisk deltagelse. Mht. til det andet spørgsmål argumenterer jeg - igen med Habermas - for, at den konkrete anvendelse af abstrakte retsprincipper som ytringsfrihed og religionsfrihed kreever åben, demokratisk debat med bred deltagelse for at have legitimitet. Resultatet af denne debat kan godt voere et strengt syn på, hvad der toeller som blasfemisk, men muligheden for at kritisere dette syn-ellerforgenerel religionskritik-kan ikke undertrykkesuden at gå kompromis med det liberale demokratis grundprincipper. Som svar på det tredje spørgsmål, og som et kritisk supplement til Habermas, fremfører jeg med Axel Honneth, at samfundsmoessig integration ikke skabes af demokratiske debatter alene. Der kreeves også en vis før-diskursiv atmosfore af solidaritet: Religiøse minoritetsgrupper kan ganske vist ikke krove juridisk beskyttelse af religiøse folelser, men de kan påpege «asymmetriske anerkendelsesforhold», f.eks. ensidigt negative fremstillinger i medierne, som forringer deres mulighed for at bidrage til samfundet som anerkendte og anerkendende medborgere.

Nøgleord: karikaturkrisen, Jürgen Habermas, Axel Honneth, religionskritik, social anerkendelse 


\section{Indledning}

Den i Danmark antændte, men snart globalt kendte karikaturkrise i 2005/ 2006 satte ikke bare en bred offentlig debat i gang i de lande, hvis ambassader brændte. Den ansporede også til en intellektuel og akademisk debat, nationalt og internationalt, samt en nu globalt intensiveret kontrovers om religion, ytringsfrihed og retten til ikke at blive krænket - eller positivt formuleret: retten til at blive anerkendt. Men på hvilket grundlag kan medlemmer af livssynspluralistiske demokratier fremsætte anerkendelseskrav til hinanden? Eller hvad med medlemmer af det globale fællesskab - menneskeheden? Kan vi fastlægge anerkendelsesbehovet - eller krænkelsens grænser - gennem lov og ret, eller står de til demokratisk debat?

Ifølge repræsentanter fra de store verdensreligioner er læren af karikaturkrisen, at den vestlige ytringsfrihed ikke kan stå alene, men må suppleres med rettigheder, der beskytter religioner og religiøse grupper mod krænkelser. I en fælles udtalelse fra Vatikanet og det sunnimuslimske al-Azharuniversitet kræves der således beskyttelse af «religioner, overbevisninger, religiøse symboler og alt som holdes hellig». ${ }^{1}$ Et andet eksempel er den heftige debat om FN's racismekonference, der skal afholdes i 2009. Konferencen er allerede døbt «Durban II», eftersom den er en fortsættelse af en konference i Durban i Sydafrika i 2001, hvor bl.a. USA og Israel udvandrede efter at muslimske lande satte lighedstegn mellem støtte til Israel og racisme. I forberedelsen til Durban II har de islamiske landes officielle organ, OIC, udfærdiget et dokument, som - med direkte reference til karikaturkrisen - også subsumerer krænkelser af religioner og religiøse symboler under racismekategorien. Karikaturernes forsvarere står derimod hårdnakket på, at demokratiet ikke er noget teselskab: Alle samfundets borgere må finde sig i spot, hån og latterliggørelse, da ytringsfrihed også er frihed til at provokere og udfordre hellige køer. Forsvarerne nægter derfor at sætte lighedstegn mellem racistiske ytringer om mennesker og karikering af religiøse symboler og figurer. ${ }^{2}$

Også internt i de europæiske demokratier synes holdningerne at være spændt ud mellem to poler: Den ene lejr mener, at religiøse grupper generelt, og muslimer i særdeleshed, utvetydigt og ubetinget må anerkende de friheds- og lighedsprincipper moderne demokratier bygger på - også selvom disse principper indimellem fører til ubehagelige oplevelser i offentligheden. Den anden lejr mener, at de europæiske majoritetskulturer må begynde at tage større hensyn til religionen og dens udøvere, særligt de muslimske, da netop muslimer er mærket af xenofobisk dæmonisering og «islamofobi».

Som en modvægt til de skråsikre enten-eller-holdninger, der præger debatten om karikaturkrisen («for eller imod Islam/ytringsfrihed/religion»), forsøger jeg i det følgende at udvide diskussionens perspektivrig- 
dom ved at anskue den i lyset af Jürgen Habermas' modernitets- og diskursteori samt Axel Honneths anerkendelsesteori.

\section{Habermas: Det post-sekulære demokratis udfordringer}

At Habermas er blevet kaldt «sekulariseringens ypperstepræst» er ikke helt berettiget, men heller ikke helt tilfældigt. ${ }^{3}$ Man kan forstå hans hovedværk fra 1981, Theorie des kommunikativen Handelns (herefter TKH), som en tilslutning til «sekulariseringstesen», dvs. den klassiske sociologiske antagelse om, at religionen forsvinder når samfundet moderniseres. Vi kan sammenfatte sekulariseringstesen i tre punkter: (a) Det naturvidenskabelige gennembrud (og dermed «verdens affortryllelse» (Weber)) fører til, at religiøse virkelighedsforklaringer mister deres legitimitet og overbevisningskraft; (b) samfundets opdeling i adskilte funktionsområder fortrænger religionen fra bl.a. politikken, retten, kulturen, uddannelsessystemet og den institutionaliserede videnskab, og gør den til et privat anliggende; (c) med et stigende velfærdsniveau mindskes behovet for de omfattende verdensforklaringer og handlingsvejledninger, som religionerne tilbyder.

Sekulariseringstesen, siger Habermas i dag, kan i nogen grad siges at beskrive udviklingen i den specifikt europæiske modernitet. Den selvsikre tro på, at den europæiske model med tiden bliver adopteret i resten af verden, er imidlertid falsificeret: Verden er så religiøs som nogensinde før, og mange verdensdele oplever ligefrem en religiøs «revitalisering»: (a) De store verdensreligioner, særligt islam og kristendom, vinder hastig udbredelse i f.eks. Afrika og Latinamerika; (b) denne udbredelse er ofte af fundamentalistisk eller konservativt tilsnit; (c) tendensen til politisk udnyttelse af religionernes voldspotentiale er stigende, f.eks. i form af islamistisk terrorisme og mobiliseringen af den kristne højrefløj i USA under Irak-krigen. Den europæiske sekularisering er med andre ord en undtagelse, ikke en regel (Habermas 2005: 121).

At sekulære europæere for nylig har fået øjnene op for at være en global minoritet, ja nærmest et særtilfælde, er en del af den bevidsthedsændring, der får Habermas til at betegne de europæiske samfund (og lignende) som post-sekuloere. To andre faktorer er erkendelsen af at (a) religiøse synspunkter i stigende grad kræves anerkendt som relevante for offentlige diskussioner; (b) indvandringen fra traditionelle, religiøse samfund fører til en ny type interreligiøse- og kulturelle konfliktpotentialer - som netop karikaturkrisen var et eksempel på (Habermas 2008). De her nævnte udviklingstræk udgør imidlertid blot en empirisk beskrivelse. Tilbage står det normative spørgsmål: Hvilken plads bør religionen have i et post-sekulært samfund? Eller nærmere bestemt: Hvad betyder adskillelsen mellem stat og kirke i dag 
for religiøse gruppers rettigheder og pligter i civilsamfund og politisk offentlighed?

\section{Mellem restriktionisme og revisionisme}

I sit seneste større værk (2005) diskuterer Habermas dette spørgsmål indgående. Diskussionens baggrund er hans kendte, men komplekse teori om deliberativt demokrati, som har rødder tilbage til hans nu klassiske hovedværk, Strukturwandel der Öffentlichkeit, fra 1962. Meget kort sagt er mennesket et væsen, som ikke blot søger tilfredsstillelse af egne interesser: Som sproglige væsner er vi dybest set interesserede $i$ at begrunde vore handlinger og holdninger for andre og opnå fælles forståelse. I moderne, demokratiske samfund har vi mulighed for gennem diskussioner og kritiske argumenter at opnå den nødvendige grad af enighed og sammenhængkraft, som i før-moderne samfund typisk er fastlagt af omfattende, religiøse verdensbilleder. Dette stiller imidlertid også krav til vores evne og vilje til at begrunde vore standpunkter og handlinger på en måde, som andre forventes at kunne indse fornuftigheden af, lytte til kritik og evt. ændre opfattelse i lyset af bedre argumenter. Vi kan ikke blive enige om fælles værdier, men om de fælles normer, der skal koordinere samlivet på trods af store værdiforskelle.

Men hvad betyder dette konkret? Hvilke typer argumenter fortjener at blive taget alvorligt i offentlige debatter? Er det et gyldigt argument mod at tegne den muslimske profet, at han ifølge den hellige Koran selv har nedlagt forbud mod det? Eller er dette kun noget muslimer kan tage hensyn til? Habermas angiver - i sin egenskab af filosof - ingen lette løsninger på sådanne spørgsmål. Men han kritiserer to mulige svar: et «restriktionistisk» og et «revisionistisk». Den «restriktionistiske» position vil udelukke religionen fra den offentlige fornuftsbrug. Det vil sige, at religiøse grupper ikke kan deltage i den offentlige debat, hvis de anvender religiøst funderede eller inspirerede argumenter som det ovenstående: Hvis man har et budskab, må man være i stand til at formulere det i strengt sekulære begreber, dvs. et for alle borgere acceptabelt sprog. Efter karikaturkrisen sluttede mange op om den denne holdning, f.eks. den danske statsminister Anders Fogh Rasmussen, der udtalte, at religion hører til i privatsfæren. Ifølge Habermas finder vi varianter af restriktionismen hos bl.a. Robert Audi og John Rawls.

Når Habermas kritiserer denne position skyldes det for det første, at han finder den uretfoerdig på liberal-demokratiske præmisser: Selvom Habermas opfordrer religiøse borgere til at formulere sig på en alment tilgængelig måde, mener han ikke, at vi kan kreve det eller fremtvinge det retsligt. Hvis andre borgere kan lufte og fremme deres livssyn offentligt, hvorfor kan da ikke religiøse? Betyder adskillelsen mellem stat og kirke ikke netop, at ingen substantielle livs- og verdenstydninger, hverken sekulære eller religiøse, har 
forrang? Udelukker staten alligevel religiøse argumenter fra den offentlige debat, tvinges religiøse borgere til at splitte deres identitet i en sekulær og en religiøs halvdel, når de veksler mellem det private og det offentlige, hvilket Habermas beskriver som et «angreb på deres selvforståelse» (Habermas 2005: 135).

For det andet er der funktionelle (dvs. socialintegrative) grunde til ikke at afskære religionen fra demokratiet og offentligheden: Hvem ved, om ikke religionerne gemmer på nogle eksistentielle og moralsk motiverende ressourcer, som moderne livsverdener og civilsamfund - truet af kapitalistisk nyttetænkning og formålsrationalisering - kunne nyde godt af?

Es wäre unvernünftig, a priori den Gedanken von der Hand zu weisen, dass die Weltreligionen - als das einzig überlebende Element aus der alten Reische - innerhalb des differenzierten Gehäuses der Moderne einen Platz behaupten, weil ihr kognitiver Gehalt noch nicht abgegolten ist (Habermas 2005: 149).

For det tredje: Ved at henvise f.eks. muslimers syn på «ytringsfrihed og religion» til skjulte baggårdsmoskeer kan vi være sikre på, at de modernitetsfjendtlige grupper ikke bliver mindre, men mere forstenede i deres modstand mod de liberale demokratiers friheds- og lighedsprincipper.

Den anden svarmulighed, «revisionismen», er et direkte opgør med det liberale demokratis sekulære grundlag og selvforståelse, mener Habermas. Som repræsentanter for denne position nævnes Paul Weithmann og Nicholas Woltersdorf, som anklages for at ville «åbne parlamenterne for trosstridigheder» (2005: 139). Habermas sigter her til, at disse teoretikere vil afskaffe det «institutionelle oversættelseskrav», dvs. kravet om, at der i den formelle offentlighed, f.eks. ministerier, offentlige institutioner og retssale, kun anvendes sekulære (fordi neutrale) termer. Ifølge Habermas må dette krav overholdes, hvis demokratiet ikke skal udarte sig til en ren kampplads mellem uforsonlige livssyn og interesser. Det institutionelle oversættelseskrav udtrykker nemlig en basal loyalitet mellem samfundsborgerne, der ikke kan fremtvinges politisk eller retsligt: De love og regler, der regulerer samfundet, skal alle borgere i princippet kunne forstå og anerkende. I stedet for et «flertalsdiktatur», f.eks. en religiøs eller kulturel majoritets «sejr» over minoriteterne, kræver Habermas' demokratiopfattelse, at der ikke blot opnås nødvendige kompromisser, men en basal, forståelsesbaseret konsensus mellem grupperne. Dette bliver imidlertid umuligt, hvis religiøse og andre synspunkter kan søges udbredt direkte gennem statsmagten og lovgivningen, som Weithmann og Woltersdorf lægger op til.

Mellem disse yderpunkter kan Habermas' pointe - som jeg forstår ham - formuleres som følger: Religiøse borgere har ret til at bruge religiøst inspirerede argumenter, og til direkte at benytte religiøst sprog i den offentlige debat. Siden statens love og institutioner udelukkende anvender sekulære grunde og argumenter, gør religiøse borgere imidlertid $k \log t i$ at oversætte 
til et alment tilgængeligt sprog, så deres synspunkter kan indoptages i den offentlige viljesdannelse. Muslimer, der vil undgå flere karikaturer, får derfor mindre ud af at lægge vægt på den muslimske profets ukrænkelighed, og mere ud af - som mange muslimer netop gjorde - at argumentere for alle menneskers ret til at have og udøve en religion uden blive nedværdiget offentligt. Men argumentet går også den anden vej: For at fremme den sociale integration og muligheden for gensidig forståelse, gør også ikke-religiøse borgere klogt i - i den demokratiske offentlighed - at forsøge sig med at uddrive en sekulær og af åbenbaringssandheder uafhængig mening af religiøst indkapslede påstande.

\section{Mellem sekularisme og radikal multikulturalisme}

I kølvandet på «11. september», «krigen mod terror», bomberne i London og Madrid, karikaturkrisen mm. har diskussionen om religion og modernitet udviklet sig til en bredere ideologisk debat om den vestlige modernitets selvforståelse - med særligt fokus på spørgsmålet om islams kompatibilitet hermed. Ironisk nok taler både «islamister» og «islamofober» samstemmende om uforeneligheden mellem islam og moderne principper som menneskerettigheder, demokrati og kønslig ligestilling. ${ }^{4}$

Habermas' bidrag til denne «nye kulturkamp» (Habermas 2008) er igen en adskillelse af to yderpunkter, der begge har noget for sig, men i sig selv er for ensidige til at være frugtbare. Den ene position kalder han «radikal multikulturalisme», da den bygger på en relativistisk forestilling om kulturer som inkommensurable verdener med hver deres epistemiske og normative begrebsapparat (Habermas 2008). At tale for den universelle gyldighed af ytringsfrihed og demokrati kan ifølge denne opfattelse kun forstås som vestlig kulturimperialisme og selvgodhed. Kulturer er lukkede meningshorisonter, og nogen «horisontsammensmeltning» (Gadamer) kan der derfor ikke blive tale om. Den oplagte kritik af denne position er naturligvis, at den frarøver sig selv enhver mulighed for at kritisere kultur-interne uretfærdigheder og overgreb, f.eks. religiøs eller kønslig diskriminering: Kulturer er a priori ufejlbarlige. Selvom Charles Taylor ikke uden videre kan sættes i bås med denne type multikulturalisme, henviser Habermas alligevel til sin diskussion med Taylor, når han skal argumentere mod positionen (Habermas 2008). Ifølge Habermas underminerer Taylors position den individualistiske kerne i det moderne frihedsbegreb ved at åbne op for retslige hensyn til gruppespecifikke anerkendelseskrav (Habermas i Taylor/Gutman 1994: 109). Man kan muligvis formulere Habermas' pointe således: Anerkender vi, at muslimer som gruppe har særlige rettigheder, der skal beskytte deres kulturelle identitet, gør vi det vanskeligt for muslimer som enkeltindivider at udvikle eller gøre op med denne identitet. ${ }^{5}$ 
Den anden ekstrem kalder Habermas «oplysningsfundamentalisme» eller «sekularisme», da den skråsikkert bekæmper enhver tendens til politisk hensyntagen til religiøse eller kulturelle grupper: Det er de religiøse grupper, der uden forbehold må tilpasse sig majoritetens politiske kultur. At tage hensyn til muslimernes billedforbud, eller give en officiel undskyldning til krænkede muslimer, er blot første skridt på vejen mod parallelsamfund og forskelsbehandling i den politiske korrektheds navn. Sekularister blæser derfor til kamp for et "farveblindt» samfund mod multikulturalisterne, der anklages for at være naive, og for at genindføre racismen $i$ antiracistisk forklædning. Desuden afviser sekularister ofte religion som sådan eller islam i særdeleshed - som et arkaisk levn fra en førmoderne fortid, og $ø n s k e r$ den fjernet fra menneskelivet og samfundet (f.eks. Richard Dawkins og Hirsi Ali). Som berørt ovenfor mener Habermas imidlertid, at de, der vil forsvare modertniteten ved at skåne den for religionen, gør moderniteten en bjørnetjeneste: Den ensidige betoning af religiøse gruppers uforenelighed med det moderne kan vise sig at blive en selvopfyldende profeti, da den marginaliserer de pågældende grupper i stedet for at invitere dem til demokratisk deltagelse. Muslimer flest kan eksempelvis ikke integreres mod deres religion, men kun med den (Habermas 2008).

Habermas er imidlertid enig med sekularisterne i, at der findes religiøse samfund midt i den vestlige modernitet, der stadig mangler at «åbne sig» ved (a) at frigive deres individuelle medlemmer til selvstændig deltagelse i civilsamfund og demokratiske offentlighed og (b) at forene deres tro med modernitetens «epistemiske situation», dvs. anerkende deres relative plads $i$ en pluralistisk mosaik af ligeberettigede livssyn og religioner. Men han er også enig med multikulturalisterne i, at kulturelle majoriteter bør udvise hensyn, og ikke ensidigt stå fast på minoriteternes pligt til tilpasning. Hvis disse to ting skal ske samtidig, kræver det imidlertid at borgerne deltager aktivt i den demokratiske deliberation: Kun gennem intersubjektive dannelsesprocesser kan majoriteten motiveres til at udvise solidaritet, og traditionelle minoriteter til at åbne sig for modernitetens friheds- og lighedsbegreber.

\section{Demokratisk offentlighed: ytringsfriheden til debat}

Ifølge Habermas er borgere i moderne demokratier altid stillet over for fordringen om at skabe konsensus, da samfundets grundværdier og -principper altid udfordres empirisk af nye situationer og konflikter. Basale lighedsog frihedsrettigheder er i sådanne situationer nødvendige, men ikke tilstrækkelige, mener Habermas. I et samfund præget af demokratisk apati og gensidig ligegyldighed kommer borgerne let til at at rette deres rettigheder mod hinanden som «våben», og mister motivationen for at udvise solidaritet. Selvom de fleste (i Vesten) kan blive enige om, at der er noget principielt 
rigtigt ved både ytringsfrihed og religionsfrihed, skal vi derfor ikke forvente ad rettens vej at kunne fastlægge de eviggyldige rammer for disse princippers konkrete anvendelse. Den situationsbestemte fortolkning af ytringsfrihedens grænse må diskuteres og defineres af et levende civilsamfund og en aktiv offentlig debat. Er det forkert at tegne Muhammed? Er det forkert at tegne ham med en bombe i turbanen? Er det forkert, hvis man gør det for at udstille de eksplosionslystne terrorister, der misbruger islam? Det er ikke nok at give et retsligt, religiøst eller moralfilosofisk svar på disse spørgsmål, hvis det skal motivere og forpligte alle samfundets borgere. For at være legitimt kan svaret kun gives som resultatet af en fair debat mellem de involverede parter. I sådanne debatter, hvor vi fortolker almene principper og regler, er det i sidste instans fortolkningen af vores forfatning eller grundlov, der står på spil. Hvilken type samfund ønsker vi? Ønsker vi et samfund, hvor ytringsfriheden systematisk bruges til at krænke og stigmatisere minoriteter? Eller et samfund, hvor man bliver hentet af politiet, hvis man har tegnet Muhammed? Eller noget midt imellem?

Ganske vist kan man ikke, på habermasianske betingelser, tale sig frem til en hvilken som helst fortolkning af karikaturkrisen. Da den demokratiske viljesdannelse forudsætter grundlæggende friheds- og lighedsrettigheder, inklusiv frihed til at kritisere (religiøse) ideologier og magtforhold, kan man eksempelvis ikke forbyde religionskritik uden at kompromittere selve legitimiteten af den demokratiske proces. Men man kan godt komme frem til en streng fortolkning af, hvad der tæller som blasfemi, f.eks. i stil med det forslag til en udvidet blasfemilov den engelske regering fremsatte (men ikke fik vedtaget) i kølvandet på karikaturkrisen.

Ifølge kritikerne af «Durban II» (se ovenfor) ønsker OIC imidlertid at sænke grænsen for religiøs blasfemi så langt, at generel religionskritik tæller som blasfemisk, og dermed kan straffes ved lov. ${ }^{6} \mathrm{Hvis}$ det er rigtigt, er OIC ikke ude på at støtte op om menneskerettigheder og demokrati (i hvert fald ikke i Habermas' forstand), men på at skåne religiøse grupper fra enhver kritik og oplevelse af ubehag i den offentlige sfære.

\section{Kommunikativ og strategisk fornuft}

Men hvordan opnås da nærmere bestemte den konsensus, Habermas plæderer for? Habermas skelner her mellem på den ene side strategiske fornuftshandlinger, hvor en aktør søger at manipulere andre (f.eks. det offentlige publikum) for at opnå bestemte mål eller effekter, og på den anden side kommunikative fornuftshandlinger, hvor aktørerne i oprigtig eftersøgning af den sande og retfærdige fortolkning af en bestemt situation, forsøger at koordinere deres handlinger ud fra en diskursivt opnået forståelse eller «indforståethed». De to fornuftsformer er potentielt i konflikt, da den stra- 
tegiske fornuft kan forvrænge muligheden for vellykket kommunikation og dermed for opnåelsen af konsensus i stridsspørgsmål.

Det er en prekær sag at bedømme, hvorvidt bestemte aktører lever op til en abstrakt teori om kommunikativ fornuft. Det er til gengæld meget nemt at beskylde andre for at manipulere, og for ikke at ville forstå. Det er imidlertid klart, at enhver trussel om vold forvrænger betingelserne for kommunikation, og må diskvalificeres. De voldsomme ambassadeafbrændinger og trusler om hævn i mellemøstlige og enkelte afrikanske lande under karikaturkrisen - udført af et klart befolkningsmindretal - behøver vi derfor ikke opholde os synderligt ved. Mere interessant er ytringer og symbolske handlinger fra fremtrædende politikere og repræsentanter for de stridende parter under krisens optakt og eskalering. At den danske statsminister, Anders Fogh Rasmussen, nægtede overhovedet at lytte til gruppen af ambassadører fra muslimske lande, der havde bedt om et møde med ham, kan ses som en strategisk handling, der imidlertid ikke førte til sit angivelige mål: at belære ambassadørerne om, at adskillelsen mellem presse og politik i Vesten er indiskutabel. Derimod førte afvisningen til en eskalering af mistilliden i den muslimske verden, og ødelagde de motivmæssige forudsætninger for at prøve at forstå, hvordan nogen kunne finde på at tegne profeten, og hvorfor de ikke blev straffet. Samtidig kan man anklage firmaer som Arla Foods eller Nestle for at udvise en rent strategisk «forståelse» for den muslimske sag for at få solgt deres varer. Nestle var f.eks. hurtige til at reklamere med at ikke at anvende mælk fra danske køer, hvormed de, som Slavoj Zizek påpeger (2006), var med til at stemple et helt land pga. en enkelt avis. Men det groveste eksempel på kommunikationsforvrængende, strategisk handlen var nok en række danske imamers udbredelse af en række meget krænkende billeder i Mellemøsten, bl.a. af profeten som gris. Billederne var ledsaget af en påstand om, at Jyllands-Posten havde udgivet disse for at håne muslimer.

Debatten i kølvandet på krisen er naturligvis vanskelig at overskue og vurdere. En række kronikker, bogudgivelser og offentlige debattanter viste eksempler på reel dialogvillighed og saglig argumentation, mens andre forskansede sig bag skråsikre holdninger - langt fra det «bedre arguments» pædagogiske rækkevidde. At debatten, særligt den internationale, bar præg af kommunikationsbrister og manglende læring, vil af nogen blive udlagt som et bevis for ubrugeligheden af Habermas' diskursteori i konkrete konflikter. Det mener jeg imidlertid er en forhastet og forkert konklusion. Hvis vi f.eks. ser på de danske muslimers reaktioner, og sammenligner dem med reaktionerne i ikke-demokratiske lande, er der klar forskel: I dansk (og europæisk) kontekst benyttede langt de fleste muslimer sig af deres demokratiske borgerrettigheder; de argumenterede, de lyttede til modargumenter, de demonstrerede fredeligt og de lagde sag an efter straffeloven. Hvis ikke det skyldes en større udvikling af de kommunikative fornuftskompetencer, hvad skyldes det så? Efter min mening kan man ligefrem argumen- 
tere for, at det var en sejr for den demokratiske dannelse, at det ikke gik mere galt end det gjorde. At meningsmålinger desuden viste, at muslimer, efter debatterne om karikaturkrisen, følte sig mindre diskriminerede i Danmark, kan muligvis tages til indtægt for dette synspunkt. ${ }^{7}$

Men hvad med selve karikaturerne, dvs. motivet bag udgivelsen? I manges øjne var Jyllands-Postens handling et klassisk eksempel på det Habermas kalder strategisk fornuft: Jyllands-Posten ville ikke vinde en forståelse med muslimer, endsige lære noget af muslimer, men gennem et mediestunt associere islam med terrorisme i den offentlige bevidsthed. Hertil må vi dog sige, at publikationen var ledsaget af en offentlig begrundelse, og derfor i en eller anden forstand var kommunikativ: Tegningerne skulle ses som en protest, ikke mod muslimer, men mod de muslimer, der truer og udøver vold for at forsvare islam mod krænkelser. Begrundelsen inkluderede en række faktiske eksempler på selvcensur i Europa efter pres eller trusler, men det angivne hovedmotiv var som bekendt at forfatteren Kåre Bluitgen ikke kunne finde nogen, der turde tegne Muhammed til en børnebog om profetens liv. Mod anklagen om blot at ville tilsvine en i forvejen udsat minoritet, hævder Jyllands-Posten altså, at motivet bag publikationen var moralsk indignation. ${ }^{8}$

Spørgsmålet er derfor, om Habermas' skelnen mellem rent kommunikative og rent strategiske handlinger alligevel er for rigid til at passe i en sag som karikaturkrisen? Er det tænkeligt, at både Jyllands-Posten og de mange protester mod avisen delvist var strategiske og delvist kommunikative? Dvs. at parterne ganske vist var orienteret teleologisk mod at opnå bestemte mål (hhv. at beskytte og provokere islam), men ikke for enhver pris: parterne havde hver for sig en stærk opfattelse af at have moralen på sin side, og et stort behov for at blive forstået sådan af andre. Vi mangler her et vokabular til at analysere sociale konflikter, der både er normative og indeholder et element af kamp eller magtudøvelse. Efter min mening har Axel Honneth i forlængelse af Habermas - givet os et godt bud på et sådant vokabular, nemlig via sin forståelse af sociale konflikter som anerkendeskampe.

\section{Axel Honneth: Protestkulturer, krænkelse og anerkendelse}

Axel Honnet siges at udgøre den kritiske teoris «3. generation» efter Adorno/Horkheimer (1. generation) og Habermas (2. generation). Honneth bygger videre på Habermas' kommunikationsteoretiske ansats. Mens Habermas tænker mest i retfærdighed og diskursteori, stiller Honneth det modige spørgsmål: Kan socialfilosofien sige noget om minimumsbetingelserne for et godt liv? Med fuld bevidsthed om, at moderne samfund netop er kendetegnet ved en pluralitet af livssyn, dvs. substantielle 
værdier, etikker, religioner osv., søger han altså et fællesmenneskeligt og tværkulturelt udgangspunkt for sin kritiske samfundsteori: Kan vi artikulere en filosofisk antropologi, der på den ene side siger noget mere om det vellykkede liv end liberalistiske retfærdighedsteorier, samtidig med at den er så formal eller «tynd», at den ikke krænker pluraliteten af livsformer? Mens det gode liv ifølge Habermas er noget, der bestandig diskuteres i demokratiske diskurser, men som falder uden for sociologiens og filosofiens område, er det altså ifølge Honneth også tema for en socialfilosofi, der vil tilbageføre samfundets patologier til en normativ teori om menneskelig identitetsdannelse eller «selvvirkeliggørelse», og ikke nøjes med at lokalisere dem i forvrængninger af vore kommunikative praksisser (som Habermas).

Honneth udformer sin teori om det gode liv som en «formal teori om anerkendelse» (Honneth 1992). Det betyder, at teorien ikke udspecificerer hvad et godt liv er, men opholder sig ved nogle grundformer for menneskelig interaktion, nemlig anerkendelsesrelationer, uden hvilke vi ikke kan udvikle vellykkede selv- og omverdensrelationer - uanset om vi f.eks. er kristne, muslimer, ateister eller noget fjerde. Uden visse former for anerkendelse kan vi nemlig ikke svare meningsfuldt på spørgsmålet: Hvem er jeg? Og omvendt: Når anerkendelsen udebliver, dvs. når vi kræenkes, krænkes vi netop i vores selvforståelse og integritetsfølelse. At blive udsat for en voldtægt, at blive nægtet grundrettigheder som menneske, at blive ringeagtet for sin hudfarve eller sin religion truer vores vigtigste og mest fundamentale evne: evnen til at opretholde en positiv selvopfattelse.

Ved på denne måde at tilbageføre den kritiske teoris normative udgangspunkt til en teori om subjektets «moralske følelser», f.eks. følelser af uretfærdighed, ydmygelse eller skam, mener Honneth i højere grad end Habermas at tage højde for de handlende aktørers egne oplevelser af, hvad der er kritisabelt og uretfærdigt i samfundet. Det er ikke først og fremmest systemets «kolonisering af vores livsverden» (Habermas), der optager os på erfaringsplanet, men den måde vi som individer, grupper og samfundsmedlemmer bliver mødt på og anerkendes (eller ikke) for det vi er og gør.

Jeg kan her på ingen måde yde Honneths komplekse og omfattende teori retfærdighed. Men jeg kan trække nogle pointer frem, som kan være relevante for vores diskussion af religiøse identiteter - $\mathrm{i}$ spændingsfeltet mellem krænkelse og anerkendelse - i den demokratiske offentlighed. Jeg vender under fremstillingen flere gange tilbage til den «kamp om anerkendelse», som ifølge Honneth motiverer sociale konflikter, og som han ikke mener Habermas er opmærksom nok på. ${ }^{9}$ 


\section{Anerkendelsens grundformer}

Honneth interesserer sig i højere grad end Habermas for det, der sker før individer træder diskursivt ind i samfundets demokratiske viljesdannelse: Hvordan sættes de overhovedet i stand til dette? Det gør de, ifølge Honneth, ved kronologisk at gennemløbe tre «stadier» af intersubjektiv anerkendelse, som tilsammen udgør de ontogenetiske minimumsbetingelser for en vellykket identitetsdannelse. Den første anerkendelsessfære kalder Honneth «kærlighed», da den udtrykkes gennem intime ansigt-til-ansigtrelationer som familie, parforhold og venskabsforhold. Mere relevant i nærværende sammenhæng er imidlertid de to næste sfærer: den retslige anerkendelse (a) og den sociale verdsettelse (b):

(a): I takt med at individet vokser op, skal det selvsagt ikke bare indgå i intime ansigt-til-ansigt- relationer (som i kærligheden), men også i et samfund af mennesker, der ikke er interesserede i dets særlige behov og emotioner. I moderne samfund, modsat før-moderne fællesskaber, er vores rettigheder og pligter ikke fastlagt $\mathrm{i}$ et kulturelt eller religiøst værdihierarki, men af en formel og livssynsneutral anerkendelse af alle individers juridiske ligeværd som mennesker. Da denne værdi tilkendes individet som rettighedssubjekt, kalder Honneth den anden anerkendelsestype for «retten» eller «retslig anerkendelse». Kun gennem erfaringen af at indgå i samfundslivet på lige fod med alle andre kan individet komme til at respektere eller agte sig selv, siger Honneth med reference til Kant. Tilsvarende krænkes individets selvrespekt når det nægtes retslig anerkendelse og dermed vises disrespekt.

Den moderne forståelse af individet som ukrænkelig rettighedsbærer er ifølge Honneth et historisk resultat af en moralsk dannelsesproces. Denne proces, mener han, kan bedst forstås som en række kampe om anerkendelse, hvor individer og grupper i konfliktuelle processer gør hinanden opmærksomme på erfaret uretsbevidsthed, dvs. oplevelser af misagtelse og krænkelser som følge af forskelsbehandling og asymmetrisk anerkendelse. Som eksempel kan vi nævne afroamerikaneres kamp i USA, arbejderbevægelsen eller kvindebevægelsen. Disse kampe angår på den ene side magt og indflydelse som ligestillede samfundsborgere, men de er ikke «strategiske» $\mathrm{i}$ Habermas' forstand, da de er motiveret af krænkelseserfaringer og viljen til at ændre moralsk illegitime strukturer i den sociale orden. Ifølge Honneth kan en del problematikker omkring slagtemetoder og religiøs beklædning i offentligheden forstås i lyset af gruppers kamp om retslig anerkendelse, da de handler om individers mulighed for at deltage på lige fod i samfundet, f.eks. i uddannelses- eller arbejdslivet (Honneth/Fraser 2003: 194f).

Lad mig her vende tilbage til min «case». Diskussionen om karikaturkrisen, og mere generelt om islam i Europa, forvirres ofte over spørgsmålet om, hvorvidt der strides om muslimers principielle ligeberettigelse i samfundet, dvs. retslig/juridisk anerkendelse, eller hvorvidt der strides om sarlige 
hensyn til muslimer, dvs. hensyn, vi ikke tager til andre. Syv muslimske foreninger lagde i 2006 sag an mod Jyllands-Posten for at overtræde blasfemiparagraffen $(\$ 140)$ i dansk lovgivning. I blasfemiparagraffen - nedskrevet i 1866 - hedder det bl.a., at «den, der offentligt driver spot med eller forhåner noget her i landet lovligt bestående religionssamfunds troslærdomme eller gudsdyrkelse, straffes med bøde eller fængsel indtil 4 måneder» ${ }^{10}$. Eftersom de syv foreninger ikke krævede en særlov, men henviste til en allerede gældende lov, som beskytter alle religiøse samfund, kan det umiddelbart se ud som om vi har at gøre med en kamp om juridisk ligestilling. Dette er imidlertid ikke tilfældet, for blasfemiparagraffen svarer ikke til den moralske virkelighed i Danmark (eller i størstedelen af Europa). Den almindelige holdning er, påstår jeg, at det i mange tilfælde er dumt og ufrugtbart at «spotte» religiøse symboler, i andre tilfælde morsomt og nødvendigt men strafbart skal det ikke være. En domfældelse mod Jyllands-Posten ville derfor have været meget opsigtsvækkende og ville have kvalificeret sig selv som reel juridisk forskelsbehandling, da blasfemiparagraffen normalt aldrig tages i brug. Med litteraturvidenskabsmanden Dennis Meyhoff må vi derfor konkludere, at blasfemiparagraffen - modsat racismeparagraffen - er «håbløst forældet» (Meyhoff 2008). At Meyhoff har ret i dette bestyrkes af den seneste udvikling i Norge, som har en lignende paragraf. Her fremsatte den siddende regering i efteråret 2008 et forslag om at afskaffe blasfemiparagraffen og erstatte den med en lov, som beskytter mod «kvalificerede angrep på religion». Efter intens debat og kritik blev det nye lovforslag trukket tilbage med den begrundelse, at der ikke var opbakning til det i befolkningen (men blasfemiparagraffen ophæves under alle omstændigheder). Samtidig bør vi ikke overse, at aktuelle europæiske tendenser trækker i retning af at gøre op med rettens kulturblindhed: I England har sharia-domstole fået delvis dømmende magt af myndighederne, og i Norge har juristen Erling Staff foreslået strafnedsættelse for æresdrab begået af muslimer, da deres kultur påbyder dem det (ifølge Staff).

Når Honneth i et interview opfordrer til ikke at føre diskussionen om karikaturkrisen på det retsligt-juridiske plan, forstår jeg det i tråd med mine her anførte forbehold mod strafferetlige sanktioner mod Jyllands-Posten (Honneth: 2006). Dette betyder imidlertid ikke, at vi ifølge Honneth ikke skal tage protesterne mod karikaturerne alvorligt eller undlade at tage hensyn til dem. Men hvis krav om anerkendelse af religiøse følelser ikke kan indløses i form af retslig anerkendelse, hvordan kan de så?

(b) Svaret på dette spørgsmål kan vi måske finde i Honneths tredje anerkendelsessfære: den sociale vardsattelse. Ifølge Honneth kræver vellykket menneskelig selvvirkeliggørelse - dvs. en sund selvidentitet - ikke alene «følelsesmæssig selvfortrolighed» (kærligheden) og «selvagtelse» (retten); den kræver også det han kalder «selv-værdsættelse». Selvværdsættelse refererer til oplevelsen af at bidrage produktivt til samfundet, først og fremmest 
gennem de præstationer og evner, der er knyttet til udførelsen af et bestemt arbejde, men også i bredere forstand som en erfaring af generel værdsættelse af de udtryk og handlinger, der er knyttet til en bestemt livsform. Hvis jeg ikke kan få et job fordi jeg hedder Muhammed, eller hvis offentlighed og medier ensidigt problematiserer min nytte for samfundet pga. min religiøst-kulturelle baggrund, kan jeg ikke udvikle en positiv opfattelse af min egen værdifuldhed for fællesskabet, påstår Honneth. Dette kan endvidere slå negativt tilbage på majoritetskulturen: Hvis bestemte grupper, f.eks. socialt og økonomisk sårbare minoriteter, falder uden for samfundets «anerkendelsesnet», vender de sig typisk mod majoritetskulturen som potentielt voldelige protestgrupper, f.eks. gennem nynazisme eller religiøs fundamentalisme.

Som et svar på kritik fra bl.a. Nancy Fraser fremhæver Honneth her, at hans analyse ikke nødvendigvis bifalder de pågældende gruppers egne forestillinger om, hvad de skal anerkendes for, og hvorfor de skal anerkendes. For eksempel afviser han den misforståelse af hans teori, at tilhørsforholdet til en bestemt religion eller kultur i sig selv kvalificerer til social værdsættelse. Hvad der tæller som et værdifuldt samfundsbidrag, og dermed udløser værdsættelsen, er i moderne samfund til bestandig debat: Personer og grupper komper om anerkendelse for deres arbejde og deres generelle samfundsværdi, f.eks. i offentlige debatter eller lønforhandlinger. Men den sociale værdsættelse tildeles netop på baggrund af individers prostationer for samfundet, dvs. at det principielt er din indsats der tæller, ikke dit køn, din sociale status eller dine kulturelle værdier. Hverken kristne, muslimer eller universitetslektorer kan som gruppe kræve $a$ priori anseelse, men må vise og argumentere for, hvad deres individuelle «medlemmer» positivt tilfører samfundet.

For at kunne vurdere nytten af forskellige samfundsbidrag kræves der ganske vist en vis grad af enighed om fælles mål: Hvis vi positivt skal kunne værdsætte hinandens handlinger - og ikke blot tolerere dem - må vi være fælles om et grundlæggende syn på, hvilken retning samfundet skal bevæge sig i, vi må dele en vordihorisont. Denne horisont er imidlertid ikke statisk, men noget, der dybest set er til debat hver gang vi diskuterer blasfemiparagraffer, lærerlønninger og benzinpriser.

Samtidig påpeger Honneth, at visse grupper ikke har en reel chance for at deltage i denne værdidebat og påvirke den offentlige viljesdannelse. Samfundets randgrupper, minoriteter og marginaliserede har vanskeligt ved overhovedet at blive «synlige» og finde en stemme i den demokratiske diskurs, dvs. markere sig i den offentlige bevidsthed. Derfor maner Honneth til solidaritet: Majoritetskulturen, med dens stærke repræsentation i medier, debatter og det offentlige rum, bør anstrenge sig for at lægge mærke til de mere usynlige og marginaliserede grupper, lytte til deres erfaringer og lade dem mærke, at de er «velkomne i kampen». Hvis man regner muslimer for 
en sådan gruppe, kan man bruge Honneths teori til at kritisere profet-karikaturerne som usolidariske: usolidariske med de mange, almindelige muslimer, som prøver at vinde fodfæste i det danske (eller andre) samfund, men som ikke har forudsætninger eller socialt overskud til at forstå karikaturerne som andet end mobning fra en ufølsom majoritet.

Der lægges blandt samfundskritikere ofte vægt på denne pointe hos Honneth: integration går gennem anerkendelse af minoriteter. Imidlertid glemmes det komplekse i Honneths position let i denne fremhævelse: som hegelianer ved Honneth, at man kun kan bruge anerkendelse til noget, hvis den gives af nogen, man selv anerkender. Ved ikke at respektere dig, fratager jeg dig netop den autonomi, med hvilken du kan respektere mig. ${ }^{11}$ Dette kalder Honneth «tvangen til reciprocitet» (Honneth 1992). Hvis enkelte religiøse grupper dybest set ikke kan respektere eller værdsætte en sekulær og areligiøs livsstil, er det derfor et åbent spørgsmål, hvorvidt de kan have gavn af at blive anerkendt $i$ et samfund som f.eks. det danske eller norske. ${ }^{12}$

Denne «gensidighedstvang» stiller os også i et andet dilemma: Hvis jeg ville anerkende dig, men reelt fornærmede dig, tæller det da som anerkendelse? Jyllands-Posten har eksempelvis argumenteret for, at karikaturerne var udtryk for inkludering af muslimer i det danske samfund: Ligesom alle andre bliver nu også muslimer provokeret offentligt. Som jeg forstår Honneth, kan vi ikke i moderne samfund i nogen endegyldig forstand indholdsbestemme, hvad der tæller som anerkendelse og hvad der tæller som krænkelse, da det er noget, der bestandigt forhandles og kæmpes om. Men han påpeger, at kampen bør være tilstræbt fair.

\section{Opsummering og udblik}

Efter min opfattelse supplerer Habermas' deontologiske og Honneths teleologiske udgave af en kritisk samfundsteori på udmærket vis hinanden. Mens Habermas hovedsaglig fokuserer på nødvendigheden af demokratiske diskurser (og på de systemiske forvrængninger heraf), fokuserer Honneth på de identitetsmæssige forudsætninger for overhovedet at kunne handle kommunikativt og deltage i den offentlige deliberation.

Jeg har forsøgt at vise, hvordan Habermas og Honneth på den ene side afviser religiøst begrundede grupperettigheder og enhver tendens til indskrænkning af muligheden for saglig religionskritik i offentligheden, mens de på den anden side opfordrer til dialog og solidaritet med samfundets minoriteter - inklusiv de religiøse. Det betyder bl.a., at disse minoriteter skal have reel demokratisk mulighed for at ytre deres modstand mod profet-karikaturerne, ligesom andre har mulighed for at argumentere for karikaturernes nødvendighed. På forhånd at afvise enhver skepsis mod karikaturerne som antidemokratisk eller fjendsk mod ytringsfriheden, er et 
tilbageslag for denne frihed, ikke et forsvar for den. Samtidig bør man heller ikke på forhånd fordømme enhver støtte til karikaturerne som «racistisk» eller «islamofobisk».

Vil man forstå og vurdere konflikter som karikaturkrisen i deres fulde, eksplosive omfang, kan man imidlertid ikke nøjes med at læse Habermas og Honneth. Honneth interesserer sig stort set ikke for aktuelle religiøse strømninger og de dagsordener de sætter nationalt og internationalt. Habermas interesserer sig ganske vist for religion som et moralsk værn mod kapitalismens «kolonisering af livsverdenen», men ud over en selvfølgelig afvisning af «fundamentalisme» synes han at opfatte religiøse samfund som magtfrie livsverdener, dvs. som kommunikativt organiserede fortolkningsfællesskaber, og har derfor ingen ideologi-kritisk analyse af mere «almindelige» religiøse fællesskaber og selvforståelser. En sådan analyse kan der ellers være brug for i lyset af det overvældende og delvist voldelige ressentiment mod Muhammed-karikaturerne, og mod andre krænkelser af religion og religiøse, på globalt plan. Det er derfor Hauke Brunkhorst påpeger over for Habermas, at det i dag ikke bare er kapitalismen, men også religiøse systemer, som truer med at kolonisere menneskets livsverden ved at forvrænge betingelserne for fri kommunikation: «Not only in Iran and the other islamic countries, but also in western countries, in particular the United States, there still exists a real threat of a colonization of the secular life-world of sceptical, intellectual criticism by neo-fundamentalist and re-empowered traditional religions» (Brunkhorst 2009). ${ }^{13}$

\section{Noter}

1 Citatet stammer fra en udtalelse gengivet i Dagsavisen d. 28.22008.

2 Se f.eks. det fælles «manifest mod islamismen» fra Salman Rudshie, Hirsi Ali og 10 andre europæiske intellektuelle: http://news.bbc.co.uk/1/hi/world/europe/4 764 730.stm

3 Udtrykket i gåseøjne er hentet fra Gloebe-Møller (1996).

4 Se f.eks. Henrik Borup Nielsens interview med Søren Krarup fra Dansk Folkeparti i Slagmark. Tidsskrift for Idehistorie (2004).

5 For en påvisning af hvordan præstestyret i Iran anvender kulturrelativistiske argumenter for at legitimere sin modstand mod FN's menneskeretigheder (og dermed kan hænge homoseksuelle med «god» samvittighed), se f.eks. Reza Afshari: Human Rights in Iran: The Abuse of Cultural Relativism. University of Pennsylvania Press, 2001. Se i øvrigt den såkaldte «Kairo-erklæring», der er OIC’s særlige fortolkning af forestillingen om menneskerettigheder: http://www.oicun.org/articles/54/1/CairoDeclaration-on-Human-Rights-in-Islam/1.html. Da FN's menneskerettighedserklæring bliver opfattet som et udtryk for vestlig kultur, omdefineres rækken af velkendte rettigheder til kun at gælde «så længe det er i overensstemmelse med sharia».

6 Se f.eks. www.durban2.dk. 
7 Se f.eks. http://www.ugebreveta4.dk/2007/4/Baggrundoganalyse/Muhammed-krisenharrensetluften.aspx.

8 At Jyllands-Posten tidligere har nægtet at trykke karikaturer af Jesus - for ikke at være stødende - kvalificerer derfor som et åbenlyst eksempel på dobbeltmoral.

9 Man kan argumentere for, at Habermas senere har taget hensyn til Honneths kritik - for eksempel ved at indføre et begreb om «kommunikativ magt» i Faktizität und Geltung, og for, at han ikke overser magten i hans analyse af «kampen om det gode argument». En nærmere diskussion heraf står imidlertid uden for denne artikels rækkevidde.

10 Bekendtgørelse af straffeloven. https://www.retsinformation.dk/Forms/R0710.aspx?id=113 401.

11 For en Honneth-inspireret læsning af Hegels anerkendelsesbegreb se Jonas Jakobsen (2006): Anerkendelse og selvidentitet. Om forsoningen mellem det gode og det moralsk gode liv hos Hegel.

12 Denne pointe uddyber jeg i et interview med «verdibørsen» d. 7.3, 2009 på NRK, P2. Programmet kan høres på http://www.nrk.no/programmer/sider/verdiboersen/

13 Se evt. Peter Sloterdijk $(2006,2007)$ eller Slavoj Zizek (2008) for to forfriskende bud på den her efterspurgte ideologikritiske tilgang til aktuelle religiøse strømninger både inden for islam, vestlig new-age buddhisme og kristendom.

\section{Litteratur}

Borup Nielsen, H. (2004) Den værnepligtige og politikeren. Samtaler med Søren Krarup og Poul Nyrup Rasmussen. Slagmark - tidsskrift for idèhistorie, 41, s. 123-146.

Brunkhorst, H. (2009) The transformation of solidarity and the enduring impact of monotheism: Five remarks. Philosophy and Social Criticism, 35, s. 93-103.

Gloebe-Møller, J. (1996) Jürgen Habermas. En protestantisk filosof. Oslo: Gyldendal.

Habermas, J. (1962) Strukturwandel der Öffentlichkeit. Frankfurt/M: Suhrkamp Verlag.

Habermas, J. (1981) Theorie des kommunikativen Handelns. Frankfurt/M: Suhrkamp Verlag.

Habermas, J. (2005) Zwischen Naturalismus und Religion. Frankfurt/M: Suhrkamp Verlag.

Habermas J. (2008) Dialektik der Sekularisierung. Blätter für deutsche und internationale Politikk, 8/2008, s. 33-46.

Honneth, A. (1992) Kampf um Anerkennung. Frankfurt/M: Suhrkamp Verlag.

Honneth, A. (2000) Das Andere der Gerechtigkeit. Frankfurt/M: Suhrkamp Verlag.

Honneth, A. (2006) Kampen om anerkendelse. Tv-interview. Lastet ned 18. mars 2009 fra http://www.dr.dk/DR2/2sektion/2006/03/02 120 628.htm

Jakobsen, J. (2006) Anerkendelse og selvidentitet. Om forsoningen mellem det gode og det moralsk gode liv hos Hegel. I Fordringen på anerkendelse, red. H. Stampe Lund, A. Petersen, M. Schramm \& R. Willig, s. 91-115. Århus: Forlaget Klim.

Jakobsen, J. (2007) Identitet og menneske-lighed. En lige ret til forskellighed? Semikolon. Tidsskrift for Idehistorie, semiotik og filosofi,14, s. 50-61. Tilgjengelig på http://www.semikolon.au.dk/pdf/semikolon14.pdf 
Meyhoff, D. (2008) Afskaf blasfemiparagraffen. Lastet ned 18. mars 2009 fra http:// avisen.dk/blogs/Meyhoff/meyhoff-afskaf-blasfemiparagraffen_2666.aspx

Slavoj, Z. (2008) Vold. Seks skeve refleksioner. Århus: Philosophia.

Sloterdijk, P. (2006) Zorn und Zeit. Politisch-psychologischer Versuch. Frankfurt/M: Suhrkamp Verlag.

Sloterdijk, P. (2007) Gottes Eifer: Vom Kampf der drei Monotheismen. Frankfurt/M: Verlag der Weltreligionen.

Taylor C. \& Gutman A. (red.) (1994) Multiculturalism. Princeton, NJ: Princeton University Press. 